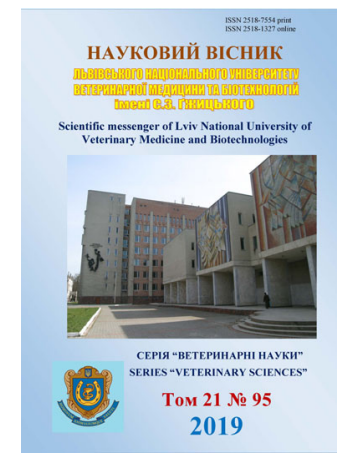

Науковий вісник Дьвівського націонадьного університету ветеринарної медицини та біотехнологій імені С.3. Гжицького. Серія: Ветеринарні науки

Scientific Messenger of Lviv National University of Veterinary Medicine and Biotechnologies. Series: Veterinary sciences

\title{
Oregano Essential Oil (Origanum vulgare L.), as a Food-supplement in a Rearing of Piglets
}

\author{
I. Salamon ${ }^{1}$, J. Poracova ${ }^{1}$, M. Hrytsyna ${ }^{2}$ \\ ${ }^{1}$ University of Presov, Slovak Republic \\ ${ }^{2}$ Stepan Gzhytskyi National University of Veterinary Medicine and Biotechnologies, Lviv, Ukraine
}

Article info

Received 09.09.2019

Received in revised form 09.10 .2019

Accepted 10.10.2019

University of Presov, 15, $17^{\text {th }}$ November St., SK-080 01, Presov, Slovak Republic.

Tel.: +421-51-757-06-62

E-mail: ivan.salamon@unipo.sk

Stepan Gzhytskyi National University of Veterinary Medicine and Biotechnologies Lviv, Pekarska Str., 50, Lviv, 79010, Ukraine. Tel.:+38-097-561-52-30 E-mail:hrytsynamr@gmail.com
Salamon, I., Poracova, J., \& Hrytsyna, M. (2019). Oregano Essential Oil (Origanum vulgare L.), as a Food-supplement in a Rearing of Piglets. Scientific Messenger of Lviv National University of Veterinary Medicine and Biotechnologies. Series: Veterinary sciences, 21(95), 55-61. doi: $10.32718 /$ nvlvet 9510

The article describes the results of the study of the physiological effect on the organism of pigs - mammals and weaned piglets. Feed additives were made from the essential oil of Origanum vulgare "Aditivum do kŕmnych zmesí na báze pamajoránu”. It has been established that O. vulgare dry grass contains essential oils $(0.15-0.50 \%)$, where carvacrol, thymol, cymol and other terpenes are main components. Extract of $O$. vulgare essential oil has a pronounced inhibitory effect on the enteropathogenic bacteria Escherichia coli hemolytic and Salmonella enteritica var. Enteritidis. In quantifying, it was found that $20 \%$ of the essential oil extract has inhibition role, which is 4 times more effective than $100 \%$, has the largest inhibitory role. The resistant symbiotic bacterium of the gut Enterococcus faecium M-7 was not affected by essential oil. The following indicators were used to establish the physiological effect of herbal supplements on the body of piglets: increasment in body weight, resistance of piglets to diseases, the state of intestinal microflora. A control and two experimental groups were added for the experiment, where the phyto-additive was included in to the feed: the first consisted of bacteria Lactobacillus plantarum with $0.05 \%$ extract of O. vulgare (LO) essential oil and the second - only $0.05 \%$ essential oil extract $O$. vulgare. $(O)$. In the two experimental groups, the pigs' health was good and their mortality was not observed either before or after weaning. The incidence was $18 \%$ before weaning and $36 \%$ after weaning in the control group. The average daily weight gaining was significant in both groups (31-36\%). Moreover, piglets were larger at birth and before weaning they increased in weight to 8 times, whereas over the next 24 days their weight increased only to $50 \%$. The difference in gaining weight between the two expirimantal groups was insignificant. The use of the herbal supplement $L O$ is more effective than $O$, because the stability index of the gut microbiota gradually increases from 2.2 to 3.37 due to decrease in the number of opportunistic bacteria Escherichia coli and enterobacteria and growth of lactobacilli. Therefore, a phyto-supplement consisting of Lactobacillus plantarum bacteria with $0.05 \% \mathrm{O}$. vulgare $(L O)$ essential oil extract can be recommended as a probiotic to feed mammals and weaned pigs for improving health and disease prevention.

Key words: essential oil, O. vulgareL., food-supplement, enzymes, microorganisms, piglet.

\section{Фітодобавка ефірної олії (Origanum vulgare L.) у раціонах поросят}

\author{
I. Саламон ${ }^{1}$, Я. Поракова ${ }^{1}$, М. Грицина ${ }^{2}$ \\ ${ }^{1}$ Прямівський університет в м. Пряшеві, Словакія \\ ${ }^{2}$ Львівський національний університет ветеринарної медицини та біотехнологій імені С.3. Гжицьького, \\ м. Львів, Україна
}

В статті описано результати дослідження фізіологічного впливу кормової фітодобавки виготовленої з ефірної олії Origanum vulgare “Aditívum do kŕmnych zmesí na báze pamajoránu” на організм свиней - сисунів і відлучених поросят. 
Встановлено, ше суха трава О. vulgare містить ефірні олії (0,15-0,50\%), де основним компонентом є карвакрол, тимол, цимол і інші терпени. Екстракт ефірних олї O. vulgare має виражену інгібуючу дію на ентеропатогенні бактерії Еsсhегіс һіа coli гемолітична i Salmonella enteritica var. Enteritidis. При кількісному визначенні було встановлено, шо найбільиу інгібуючу роль має 20\% екстракт ефірної олї, який є в 4 рази ефективніший від концентрату (100\%). На резистентну симбіотичну бактерію кишківника Enterococcus faеcium M-7 ефірна олія не впливала. Для встановлення фізіологічного впливу фітодобавки на організм поросят використовували такі показниками: збільшення маси тіла, стійкість поросят до захворювань, стан мікрофлори кишківника. Для досліду було підібрано і сформовано три групи поросят: першу - контрольну $і$ дві дослідні. Першій дослідній групі додавали до корму фітодобавку в склад якої входили бактерії Lactobacillus plantarum з 0,05\% екстрактом ефірної олї O. vulgare (LO). В склад кормів іншої дослідної групи входив лше 0,05\% екстракт ефірної олї О. vиlgаге. (O). У всіх дослідних групах стан здоров'я поросят був задовільним і не спостерігалося їхньої смертності. В процесі дослідження встановлено, ш⿻о у контрольній групі захворюваність становила 18\% перед відлученням і 36\% після нього. Середньодобовий приріст маси тіла у обох дослілних групах був 31-36\%, порівняно з контрольною. Поросята даних груп при народженні мали вищу масу тіла, а при відлученні збільшили свою масу у 8 раз, тоді як за наступні 24 доби їх маса збільшилася тільки на 50\%. Різниия у масі між двома дослідними групами була не верігодною. Використання фітодобавки LO є більш ефективним, ніж О, тому шо індекс стабільності мікрофлори кишечнику поетапно зростає від 2,2 до 3,37 за рахунок зниження кількості умовнопатогенних бактерій Escherichia coli $і$ ентеробактерій та зростання лактобактерій. Отже, фітодобавку до складу якої входять бактерії Lactobacillus plantarum з 0,05\% екстрактом ефірної олії О. vulgare (LO) можна рекомендувати як пробіотик і пребіотик для годівлі поросят-сисунів і відлучених поросят для покращення стану здоров'я і профілактики захворювань.

Ключові слова: ефірна олія Origanum vulgare, фітодобавка, Lactobacillus plantarum, приріст маси тіла, мікрофлора кишківника.

\section{Вступ}

Підвищення ефективності кормів є основним аспектом виробництва продукції тваринництва, джерела високоякісного тваринного білка, яке відповідає жорстким правилам безпечного харчування. Нинішня тенденція зниження використання синтетичних речовин як у харчуванні, так і в профілактиці і лікуванні захворювань та намагання замінити їх продуктами природного походження, дає можливості для широкого застосування кормових добавок. Фітодобавки (екстракти лікарських рослин) представляють реальну і ефективну альтернативу антибіотикам і хіміотерапевтичним засобам. Вони є екобезпечними і підвищують ефективність кормів, що забезпечує отримання більш екологічно безпечної продукції тваринництва (Darmohray, 2012; Darmohray \& Gonchar, 2015; Darmohray et al., 2018; Martyshuk \& Gutyj, 2019; Stybel et al., 2019).

Однією з цінних ефіроолійних рослин є материнка звичайна (Origanum vulgare L.), яка широко використовується в медицині, косметології, кулінарії і може застосовуватися у годівлі тварин. Вона виявляє високу антибактеріальну і антиоксидантну активність та протигрибкову дію завдяки наявності в ній ефірних олій, флавоноїдів, глікозидів.

В загальному, вміст ефірних олій в траві $O$. vulgare становить $0,03 \%-4,6 \%$ і коливається у рослин, зібраних у різних місцезростаннях та залежить від температури, сонячної радіації, топографічних особливостей місцезростання (Lukas et al., 2015). Рослини, що ростуть в Середземномор'і містять більшу кількість ефірних олій, а в їх складі переважає цимилта ациклічний ліналоол / ліналілацетат - хемотип. У популяцій, що ростуть в регіонах 3 континентальним кліматом переважає сабініл-хемотип. Серед популяцій, що ростуть в Італії також виділяють три хемотипи залежно від умов зростання: 3 переважанням карвакролу / тимолу; тимолу / $\alpha$-терпінеолу; ліналілацетату і ліналоолу (найнижчий вміст фенолів) (De Martino et al., 2009).
Другим важливим компонентом $O$. vulgare $\epsilon$ флавоноїди та фенольні кислоти. У цього виду виявлено високий вміст розмаринової (23 мг/г) кислоти, а також лютеолін-7-O- $\beta$-D-глюкуронід, тоді як протокатехін, 3-О-кафеїлхінінова і кофеїнові кислоти були в незначній кількості (Milevskaya et al., 2017). У надземній частині O. vulgareL. ssp. hirtum було виявлено чотирнадцять летючих агліконів, які були ідентифіковані з тимохіноном, а також бензиловий спирт, евгенол, 2-феніл-етанол, тимол, 3-гексен-1ол і карвакрол. Вони проявляли антиоксидантну дію, яка за активністю прирівнюється до $\alpha$-токоферолу (Milos et al., 2000).

Ефірні олії кориці, орегано і чебрецю виявляли сильну антимікробну активність до патогенних бактерій Listeria monocytogenes, Salmonella Typhimurium, ентерогеморагічна Escherichia coli O157: Н7 та бактерій, що викликають псування продуктів (Brochothrix thermosphacta та Pseudomonas fluorescens). Тому O. vulgare може служити важливою природною альтернативою консервантів для запобігання росту бактерій у харчових продуктах (Mith et al., 2014).

В іншому експерименті була виявлена сильна дія екстракту O. vulgare на 10 бактерій: Escherichia coli ATCC 25922, Klebsiella pneumoniae, Proteus mirabilis, Pseudomonas aeruginosa ATCC 27835 і інші. Їхня дія була сильніша проти грампозитивних патогенів Staphylococcus epidermidis (ATCC 12228), ніж проти грамнегативних E. coli (De Martino et al., 2009). O. vulgare можна раціонально застосовувати в харчових продуктах як для пригнічення росту Staphylococcus aureus, так і для пригнічення синтезу стафілококових ентеротоксинів. Сильну антимікробну активність на типові штами бактерій появляє філогенетично близький до O. vulgare - чебрець (Thymus vulgaris L.) (Salamon et al., 2018).

В літературі відмічено достатньо інформації про фітохімічний склад сировини ефіроолійних рослин, їх властивості та використання. Проте, мало відомо про використання лікарських рослин у ветеринарії (Salamon \& Hrytsyna, 2019). Екстракти, отримані 3 ароматичних і лікарських рослин мають чіткий анти- 
септичний, ароматерапевтичний, протидіарейний та стимулюючий ефект і благотворно впливають на травлення. Ці речовини все частіше використовуються у вигляді кормових добавок в годівлі тварин, щоб покращити стан їх здоров'я i, таким чином, виробляти здорову їжу тваринного походження (Darmohray et al., 2019).

Кормові добавки визначаються "Свропейською Директивою про кормові добавки 70/524” - як речовини або препарати, що містять інгредієнти, які після включення їх в корм впливають на його властивості, ріст, розвиток тварин і продукцію тваринництва. Ми можемо розділити кормові добавки на чотири основні категорії: харчові добавки, ад'юванти (допоміжні речовини), добавки, що підвищують виробництво продукції, і агенти, що запобігають захворюванню тварин. На практиці для підвищення ефективності виробництва свинини використовують різні кормові добавки (білок, вітаміни, мінеральні речовини та інші). В літературі знаходимо відомості про використання мікроелементів як кормових добавок в годівлі поросят (Iskra, 2012; Shesterynska et al., 2014).

Фітогенні добавки - це добавки рослинного походження, а їх використання у годівлі тварин є перспективним для профілактики захворювань. Фітокормовими добавками є екстраговані 3 ефіроолійних рослин, наприклад, материнки звичайної (O. vulgare), чебрецю звичайного (Thymus vulgaris L.) чи сальвії лікарської (Salvia officinalis L.) ефірні олії. Вони мають бактерійну дію і можуть бути альтернативою синтетичним антимікробним препаратам. Фітодобавки в досліді покращували апетит і, як наслідок, у поросят спостерігалося збільшення маси тіла, зменшенння діареї та зниження смертності (Marcin et al., 2004). Часто в склад кормових добавок входять пробіотики (лактобактерії чи біфідобактерії), які нормалізують склад i функції мікрофлори. Використання таких фітодобавок дає можливість отримання більш екологічно безпечної продукції тваринництва, що важливо для їх застосування в практиці сільського господарства.

У Словаччині отримано внутрішній стандарт “Aditívum do kŕmnych zmesí na báze pamajoránu”, aвтор - Маріан Деметра. Стандарт поширюється на виготовлення, випробування, оцінку та реалізацію "Комбікормової добавки на основі Origanum vulgare", яка містять біологічно активні речовини - ефірні олії і лактобактерії. Призначена вона для поросят - сисунів і відлучених поросят і використовується з метою покращення їх виживання в ювенільному віці.

Метою нашої роботи було вивчення фізіологічного впливу фітодобавки “Aditívum do kŕmnych zmesí na báze pamajoránu” на організм поросят-сисунів і щойно відлучених поросят за такими показниками: динаміка маси тіла після іiі застосування, кількість інфекційних захворювань у господарстві та стійкість до них поросят.

\section{Матеріал і методи досліджень}

Для досягнення мети проводили такі дослідення: вивчення кількісного і якісного складу ефірних олій та їх бактерійної дії на хвороботворні мікроорганізми in vitro $\mathrm{i}$ in vivo.

Дослідження проводили на фермі пана Маріана Деметра в селі Чакрів. Поросяти вирощували разом із свиноматкою. Мікроклімат забезпечували електричні калорифери та вентилятори. Поросят розділили на три групи: перша контрольна група - 11 поросят, яких годували без будь-яких добавок, друга дослідна група - 9 поросят, яким включали до раціону Lactobacillus plantarum 3 0,05\% екстрактом ефірної олії Origanum vulgare (LO) і третя дослідна група (8 поросят) включали до раціону лише $0,05 \%$ екстракт ефірної олії $O$. vulgare $(\mathrm{O})$. Експеримент проводився на породі свиней словацького білого благородного $\times$ п'єтрена. Відлучення поросят проводили у віці 28 діб. Всіх експериментальних тварин годували спеціальним комбікормом без застосування кормових добавок, крім дослідно введених.

Ефірна олія була отримана дистиляційним апаратом (Oravec et al., 1988), спеціально розробленим для ароматичних та лікарських рослин. Використовували тип дистиляційного апарату "HV-300" (висота: 3400 мм, ширина: 1300 мм, 3 контейнером для 4050 кг сухої рослинної сировини та 100-120 кг свіжого рослинного матеріалу). Взимку для дистиляції ефірної олії використовували сухі рослини і масовий вихід ефірної олії був вищий. Контейнери ефірної олії зберігали під $\mathrm{N}_{2}$ при $+4{ }^{\circ} \mathrm{C}$ у темному місці.

Складники ефірної олії Origanum vulgare визначали за допомогою GC-MSD системи на пристрої Varian 450-GC разом з Varian 220-MS з портом ін'єкції SplitSplitless, детектором MSD у лабораторії "Calendula" Пряшівського університету. Було використано дві колони: RX-5MS (неполярна), $30 \mathrm{~m} \times 0,25 \mathrm{~mm}$, 3 внутрішнім діаметром: 0,25 $\mu \mathrm{m}$, газ-носій: гелій (21 psi) 3 потоком 1,50 мл.Хв-1 і колонка BPX-5MS (полярна), довжиною $50 \mathrm{~m} 3$ внутрішнім діаметром 0,25 $\mathrm{mm}$ та с товщиною стаціонарної фази $0,25 \mu \mathrm{m}$. Температурна програма: $50{ }^{\circ} \mathrm{C}-0$ хв; $3{ }^{\circ} \mathrm{C} \mathrm{хв}{ }^{1}$ до $250{ }^{\circ} \mathrm{C} ; 250{ }^{\circ} \mathrm{C}-$ 15 мін ${ }^{1}$. Ідентифікація окремих компонентів ефірної олії була зроблена з використанням часів утримання 20 автентичних стандартів компонентів фірм: Extrasynthese, Merck, Fulka i Sigma-Aldrich.

Мікробіологічні аналізи інгібуючої активності ефірних олій проводилися в Пряшівському університеті, а обидва штами бактерій були надані Інститутом фізіології тварин САН в Кошице. Інгібуючу дію ефірної олії при різних концентраціях $(100,80,60,40,20$, $1,0,1 \%$ ) визначали на двох індикаторних штамах ентеропатогенних бактерій, виділених з ректальної частини травного тракту свиней: Escherichia coli, К антиген позитивна, гемолітична і Salmonella enteritica різновид Enteritidis. При проведенні напівкількісного аналізу в рідкому культуральному середовищі, культури штаму наносили на соєвий бульйон Триптиказе i додавали тестовану ефірну олію. Отримані таким 
чином зразки культивували в стандартних умовах $\left(37{ }^{\circ} \mathrm{C}, 24\right.$ год). Наприкінці цього культивування оптичну щільність $\left(\mathrm{OD}_{600}\right)$ при довжині хвилі 600 нм, тобто зростання (або інгібування росту) досліджуваного мікроорганізму в присутності відповідної концентрації ефірної олії оцінювали спектрофотометрично, і кількість клітин при найвищих і найнижчих розведеннях визначали кількісно.

В фекаліях свиней визначали кількість таких мікроорганізмів: Lactobacillus plantarum L81 (MRS + Rif 100 qm/мл), загальна кількість лактобацил (MRS), загальна аеробіка (TSA), загальні анаероби (Schaedler agar), Enterobacteriaceae (Ендо агар), Escherichia coli (MC), загальні ентерококи. Дослідження проводили починаючи з 21 доби життя через тиждень в чотирикратній повторності.

Кількісне визначення бактерій в 1 г вмісту прямої кишки проводили за числом колоній, що виросли на середовищах, через добу інкубації в термостаті при $37^{\circ} \mathrm{C}$. Одержаний результат виражали в десятковому логарифмі колонієутворюючих одиниць в 1 г вмісту (lg КУО/г).

\section{Результати та їх обговорення}

Материнка звичайна (O. vulgare) - багаторічна трав'яниста рослина, висотою від 0,20 до 0,50 м 3 червоними або рожевими суцвіттями. Вид поширений на сухих і теплих місцях.

Згідно літературних даних суха сировина O. vulgare, зібрана в Італії давала жовто-червонуваті олії, що характеризуються типовим запахом з виходом 2,35\%, 3,15\% і 2,93\% ефірної олії (De Martino et al., 2009). У “Державну фармакопею України”, 2014 входить трава Origanum onites L. або O. vulgare L. subsp. hirtus, або суміш обох видів (Огіgani herba, OREGANO). Вміст ефірної олії становить не менше 25 мл/кг, у перерахунку на безводну сировину; сума карвакролу та тимолу не менше $60 \%$ у ефірній олії. Origanum $^{\mathrm{N}}$ - національний опис, висушена трава O. vulgare, зібрана у фазу цвітіння. Вміст: сума флавоноїдів: не менше 1,5\% у перерахунку на лютеолін 7глюкозид і суху сировину; ефірна олія: не менше 1 мл/кг, у перерахунку на суху сировину для цілої сировини та не менше 0,8 мл/кг, у перерахунку на суху сировину для різаної сировини.

Внаслідок проведених досліджень було встановлено, що суха трава $O$. vulgare містить переважно ефірні олії $(0,15-0,50 \%)$, де основним інгредієнтом $\epsilon$ карвакрол, тимол, цимол і інші терпени. Результати аналізу ГХ і фізичні властивості ефірної олії наведені в таблиці 1.

Як було представлено в попередніх дослідженнях (Poracova \& Sutiakova, 2003), ефірні олії O. vulgare мають виражену інгібуючу дію у концентраціях 100, $80,60,40$ і $20 \%$, окрім 1 і 0,1\%, на ентеропатогенні бактерії - Escherichia coli, К антиген позитивна, гемолітична і Salmonella enteritica різновид Enteritidis. Тоді як резистентна симбіотична бактерія кишківника Enterococcus faecium M-7 була стійкою до екстракту ефірної олії $O$. vulgare. Інгібуючу роль мала лише найвища концентрація - 100\% і частково - 80\%.

При кількісному визначенні (табл. 2) інгібуючої ролі екстракту $O$. vulgare на Escherichia coli та Salmonella enterica var. Enteritidis було встановлено, що найбільший вплив має ії розчин концентрацією від 80 до $20 \%$.

\section{Таблиця 1}

Якісний і кількісний склад ефірної олії $O$. vulgare і їі фізичні властивості

\begin{tabular}{|c|c|c|}
\hline Хімічні та фізичні параметри & MJ & Встановлене значення $(\mathrm{M} \pm \mathrm{m})$ \\
\hline Питома вага ( Ph . Eur., 1997) & Г. $\mathrm{cM}^{-3}$ & $0,970 \pm 0,002$ \\
\hline Оптичне обертання ( Ph . Eur., 2001) & - & $1,516 \pm 0,001$ \\
\hline Хроматографічний спектр: & \% в ефірної олії & \\
\hline - карвакрол & & $55,21 \pm 3,0$ \\
\hline - тимол & & $16,04 \pm 1,5$ \\
\hline - мірцен & & $3,0 \pm 0,5$ \\
\hline - терпінен & & $5,0 \pm 1,0$ \\
\hline - ізопропілтолуол & & $4,0 \pm 1,5$ \\
\hline - каріофілен & & $4,5 \pm 0,5$ \\
\hline - терпінеол & & $6,0 \pm 2,5$ \\
\hline запах & - & відповідає \\
\hline колір & - & червоно-корисчневий \\
\hline вода в ефірних оліях & - & немає \\
\hline
\end{tabular}

Таблиця 2

Тестування інгібування дії ефірної олії $O$. Vulgare на бактерій різних штамів

\begin{tabular}{|c|c|c|c|c|c|c|c|}
\hline \multirow{2}{*}{ Штам бактерій } & \multicolumn{7}{|c|}{ Концентрація застосовуваної ефірної олії (\%) } \\
\hline & 100 & 80 & 60 & 40 & 20 & 1 & 0,1 \\
\hline Escherichia coli & $\begin{array}{l}\text { OD } 6000,170 \\
\left(0 \mathrm{KVO}^{-1}\right)\end{array}$ & $\mathrm{OD}_{600}$ & OD 600 & OD 600 & $\mathrm{OD}_{600} 0,046$ & $\begin{array}{c}\mathrm{OD}_{600} 1,203 \\
\end{array}$ & $\begin{array}{c}\text { OD }_{600} 1,508 \\
\left(0^{8}\right.\end{array}$ \\
\hline $\begin{array}{l}\text { Salmonella enterica var. } \\
\text { Enteritidis }\end{array}$ & $\begin{array}{c}\text { OD } 600 \\
0,212 \\
\left.\left(0 \text { КУО }^{-1}\right)^{-1}\right)\end{array}$ & $\begin{array}{l}\text { OD } 600 \\
0,090\end{array}$ & $\begin{array}{l}\text { OD } 600 \\
0,089\end{array}$ & $\begin{array}{c}\text { OD } 600 \\
0.092\end{array}$ & $\begin{array}{l}\mathrm{OD}_{600} 0,068 \\
\left(0 \text { КУО мл }^{-1}\right)\end{array}$ & $\begin{array}{c}\text { OD }_{600} 1,120 \\
\left(1,1 \times 10^{8} \mathrm{KУO}^{-1}\right)\end{array}$ & $\left.\begin{array}{c}\mathrm{OD}_{600} 1,559 \\
\left(10^{8}-10^{11} \text { КУО мл }\right. \\
-1\end{array}\right)$ \\
\hline
\end{tabular}

Позначення: (OD 600$)$ - оптична щільність при довжині хвилі 600 нм, (КУО) - колонієутворюючі одиниці 
Причому, найбільшу інгібуючу роль має $20 \%$ екстракт, який $є$ в 4 рази ефективніший від 100\%. Екстракт найнижчої концентрації майже не проявляв інгібуючих властивостей.

Наступним етапом дослідження було з'ясування впливу на стан здоров'я поросят 0,05\% екстракту ефірної олії $O$. vulgare, як кормової добавки в двох варіантах: перший - 3 додаванням бактерій Lactobacillus plantarum, другий - без бактерій. В про- цесі експерименту в дослідних групах не спостерігалося смертності поросят ні до, ні після відлучення (табл. 3). У контрольній групі смертність поросят становила 9\%. Стан здоров'я в обох групах поросят був задовільним до і після відлучення від свиноматки, тоді як у контрольній групі кількість випадків захворювання становила 18\% перед і $36 \%$ після відлучення. Отже, використання фітодобавок до кормів мало позитивний ефект.

Таблиця 3

Кількісні та якісні показники піддослідних поросят

\begin{tabular}{lccc}
\hline \multicolumn{1}{c}{ Показники } & Контрольна & I експериментальна група (LO) & II експериментальна група (O) \\
\hline Кількість народжених тварин & 11 & 9 & 8 \\
Смертність до відлучення (\%) & 9 & 0 & 0 \\
Смертність після відлучення (\%) & 0 & 0 & 0 \\
Захворюваність до відлучення (\%) & 18 & 0 & 0 \\
Захворюваність після відлучення (\%) & 36 & 0 & 0 \\
Середньодобовий приріст (\%) & 0,112 & 0,157 & 0,151 \\
\hline
\end{tabular}

Згідно літературних джерел поросята народжуються менш дорозвиненими, порівняно 3 телятами і ягнятами. Маса їх тіла при народженні повинна складати 0,7-1,0\% маси тіла матері. У нашому дослідженні середньодобовий приріст маси також був вищим у групах, де використовували добавки до раціону (табл. 3). Поросята від народження до відлучення збільшили живу масу в 8 раз, тоді як за наступні 24 доби вона зросла тільки на 50\% (табл. 4). Різнииця в прирості між контрольною групою і двома дослідни- ми становила в момент відлучення 21 і 23\% в кожній дослідній групі (відповідно, LO і O) і зростала на 14\% (LO) i 9\% (O) в перший тиждень після відлучення та на 3\% (LO) і 7\% (O) - за наступний тиждень. Різниця в прирості між двома дослідними групами була невеликою. До відлучення дослідна група поросят, яким до раціону окрім ефірних олій давали лактобактерії Lactobacillus plantarum мали вищу масу на 300 г, однак до кінця експерименту різниця між їхньою масою була на 138 грам меншою.

\section{Таблиця 4}

Інтенсивність росту піддослідних поросят

\begin{tabular}{lccc}
\hline & \multicolumn{3}{c}{ Середня маса поросят $(x \pm \mathrm{t} . \mathrm{s} x[0,05 \%])(2)$} \\
\hline Вік (днів) & контрольна & 2 Дослідна група LO (9 голів.) & 3 Дослідна група О (8 голів.) \\
\hline При народженні & $807 \pm 8$ & $764 \pm 10$ & $880 \pm 12$ \\
21 -ша доба життя & $4403 \pm 16$ & $4405 \pm 14$ & $4151 \pm 5$ \\
28 доба (відлучення) & $4440 \pm 14$ & $5601 \pm 21$ & $5791 \pm 28$ \\
35 доба & $4481 \pm 13$ & $6818 \pm 32$ & $6550 \pm 33$ \\
42 доба & $4512 \pm 32$ & $7370 \pm 23$ & $7237 \pm 47$ \\
\hline
\end{tabular}

Антимікробні властивості ефіроолійного екстракту O. vulgare на організм поросят досліджували шляхом вивчення мікрофлори кишківника. На основі статистичного достовірного визначення кількості мікроорганізмів було встановлено, що порівняно 3 контрольною групою, вміст бактерій в кишківнику поросят знизився в середньому на 20-30\% при використанні фітодобавок в двох варіантах: лише ефірної олії O. vulgare та 3 додаванням до неї лактобактерій (табл. 5, 6). Як видно з таблиці 6 між дослідними групами також є відмінності.

\section{Таблиця 5}

Динаміка мікрофлори кишківника в контрольній групі поросят $\left(\mathrm{K}, 10^{8}\right)$

\begin{tabular}{|c|c|c|c|c|}
\hline \multicolumn{5}{|c|}{ Кількість мікроорганізмів, виражених у $\lg$ КУО/г вмісту $\left(x \pm \mathrm{t}\right.$. $\left.\mathrm{s}_{x}[0,05 \%]\right)$} \\
\hline & День 21 & День 28 & День 35 & День 42 \\
\hline Загальні анаероби & $12,51 \pm 0,071$ & $12,42 \pm 0,01$ & $11,82 \pm 0,06$ & $11,41 \pm 0,06$ \\
\hline Загальна аероби & $11,52 \pm 0,068$ & $12,31 \pm 0,19$ & $13.49 \pm 0,08$ & $13.23 \pm 0,07$ \\
\hline Escherichia coli & $10,37 \pm 0,052$ & $10,27 \pm 0,01$ & $9,21 \pm 0,07$ & $8,85 \pm 0,04$ \\
\hline Ентеробактерії & $10,74 \pm 0,056$ & $10,41 \pm 0,05$ & $9.25 \pm 0,061$ & $8.59 \pm 0,05$ \\
\hline Ентерококи & не визначено & $7,77 \pm 0,04$ & $8.15 \pm 0,05$ & $7.45 \pm 0,03$ \\
\hline Загальні лактобактерії & $11,76 \pm 0,065$ & $11,51 \pm 0,06$ & $11,37 \pm 0,06$ & $11,47 \pm 0,06$ \\
\hline Лактобацили стійкі до рифампіцину & не визначено & $3,50 \pm 0,05$ & $5,67 \pm 0,07$ & $5,99 \pm 0,08$ \\
\hline Індекс стабільності мікрофлори кишечнику & 2,79 & 3,19 & 3,87 & 4,18 \\
\hline
\end{tabular}


Так, кількість Escherichia coli i ентеробактерій знизилася під час експерименту в дослідній групі LO, залишившись у групі О практично незмінною. За більш високий бактеріостатичний ефект, ймовірно, відповідають лактобактерії.

Індекс стабільності мікрофлори кишечнику (ICМК), який є співвідношенням біфідо- і лактобактерій до загальної кількості кишкової палички говорить про стан кишкової флори, оскільки біфідо- і лактобактерії регулюють кількісний та якісний склад кишкової мікрофлори у нормі та затримують зростання i розмноження у ньому патогенних та умовнопатогенних бактерій. У першому досліді індекс (IC-
МК) поетапно зростав від 2,2 до 3,37 за рахунок зниження кількості умовно-патогенних бактерій (Escherichia coli i ентеробактерій) та використання як біодобавки ефірних олій $O$. vulgare 3 бактеріями Lactobacillus plantarum. Тоді як у другому досліді, цей індекс коливався від 2,18-2,39 та був досить низьким і стабільним, що зумовлено антимікробною дією лише ефірної олії $O$. vulgare. В порівнянні 3 літературними даними (Peleno, 2019) індекс стабільності мікрофлори кишківника в інтактних поросят 24-місячного віку дорівнював 3,0, а за нематодознопротозоозної інвазії падав від 2,2 до 1,5.

Таблиця 6

Динаміка мікрофлори кишківника поросят в дослідних групах

\begin{tabular}{|c|c|c|c|c|c|c|c|c|}
\hline \multicolumn{9}{|c|}{ Кількість мікроорганізмів, виражених у $\lg$ КУО/г вмісту $\left(x \pm \mathrm{t}\right.$. $\left.\mathrm{S}_{x}[0,05 \%]\right)$} \\
\hline & \multicolumn{4}{|c|}{ дослідна група LO, $10^{7}$} & \multicolumn{4}{|c|}{ дослідна група $\mathrm{O}, 10^{7}$} \\
\hline & День 21 & День 28 & День 35 & День 42 & День 21 & День 28 & День 35 & День 42 \\
\hline \multirow{2}{*}{ Загальні анаероби } & 9,69 & 9,78 & 9,53 & 9,20 & 9,81 & 9,57 & 9,45 & 10,05 \\
\hline & $\pm 0,042$ & $\pm 0,04$ & $\pm 0,04$ & $\pm 0,04$ & $\pm 0,02$ & $\pm 0,02$ & $\pm 0,02$ & $\pm 0,03$ \\
\hline \multirow{2}{*}{ Загальна аероби } & 9,54 & 10,09 & 10,88 & 10,67 & 10,16 & 10,51 & 10,81 & 10,13 \\
\hline & $\pm 0,041$ & $\pm 0,05$ & $\pm 0,06$ & $\pm 0,05$ & $\pm 0,02$ & $\pm 0,03$ & $\pm 0,04$ & $\pm 0,02$ \\
\hline \multirow{2}{*}{ Escherichia coli } & 8,59 & 8,42 & 7,43 & 7,14 & 8,42 & 8,24 & 8,48 & 8,18 \\
\hline & $\pm 0,039$ & $\pm 0,05$ & $\pm 0,04$ & $\pm 0,04$ & $\pm 0,02$ & $\pm 0,01$ & $\pm 0,02$ & $\pm 0,01$ \\
\hline \multirow{2}{*}{ Ентеробактерії } & 8,51 & 8,53 & 7,46 & 6,93 & 8,44 & 8,23 & 8,56 & 8,30 \\
\hline & $\pm 0,038$ & $\pm 0,04$ & $\pm 0,03$ & $\pm 0,03$ & $\pm 0,02$ & $\pm 0,01$ & $\pm 0,03$ & $\pm 0,02$ \\
\hline \multirow{2}{*}{ Ентерококи } & не & 6,37 & 6,57 & 6,01 & 4,10 & 4,50 & 4,34 & 4,53 \\
\hline & визначено & $\pm 0,03$ & $\pm 0,033$ & $\pm 0,31$ & $\pm 0,01$ & $\pm 0,02$ & $\pm 0,01$ & $\pm 0,03$ \\
\hline \multirow{2}{*}{ Загальні лактобактерії } & 9,16 & 9,28 & 9,17 & 9,25 & 9,59 & 9,09 & 9,06 & 9,55 \\
\hline & $\pm 0,040$ & $\pm 0,05$ & $\pm 0,04$ & $\pm 0,04$ & $\pm 0,04$ & $\pm 0,02$ & $\pm 0,02$ & $\pm 0,04$ \\
\hline Лактобацили стійкі до рифампіцину & $\begin{array}{c}\text { не } \\
\text { визначено }\end{array}$ & $\begin{array}{c}2,82 \\
\pm 0,02\end{array}$ & $\begin{array}{c}4,57 \\
\pm 0,03\end{array}$ & $\begin{array}{c}4,83 \\
\pm 0,04\end{array}$ & - & - & - & - \\
\hline Індекс стабільності мікрофлори кишечнику & 2,2 & 2,57 & 3,12 & 3,37 & 2,31 & 2,26 & 2,18 & 2,39 \\
\hline
\end{tabular}

Внаслідок проведених досліджень з'ясовано незначне переважання аеробних бактерій над анаеробними. Це обумовлено, на нашу думку, молодим віком поросят і недостатньою сформованістю травної, імунної і кровоносної систем.

Отже, використання фітодобавки ефірної олії O. vulgare (LO) 3 бактеріями Lactobacillus plantarum є більш ефективним профілактичним засобом, ніж фітодобавки лише з ефірною олією (O).

\section{Висновки}

1. Суха трава Origanum vulgare містить переважно ефірні олії $(0,15-0,50 \%)$, де основним інгредієнтом є карвакрол, тимол, цимол і інші терпени.

2. При кількісному визначенні було встановлено, що найбільшу інгібуючу роль має $20 \%$ екстракт ефірної олії $O$. vulgare на ентеропатогенні бактерії Escherichia coli, гемолітична і Salmonella enteritica var. Enteritidis. Резистентна симбіотична бактерія кишківника Enterococcus faecium М-7 до нього була стійкою.

3. У двох експериментальних групах не спостерігалося смертності поросят ні до, ні після відлучення від свиноматки. Стан здоров'я був хорошим і середньодобовий приріст ваги був суттєвий (31-36\%) в обох групах до і після відлучення. Тоді як у контрольній групі захворюваність становила 18\% перед i $36 \%$ після відлученням, а також спостерігалася смертність до відлучення.

4. Поросята при народженні були більші, до відлучення вони збільшили в вазі у 8 раз, тоді як за наступні 24 дні їх вага збільшилася тільки на 50\%. Різниця в прирості між двома дослідними групами була несуттєвою.

5. Використання фітодобавки LO (бактерії Lactobacillus plantarum 3 0,05\% екстрактом ефірної олії $O$. vulgare) є більш ефективним, тому що індекс стабільності мікрофлори кишечнику поетапно зростав від 2,2 до 3,37 за рахунок зниження кількості умовнопатогенних бактерій (Escherichia coli i ентеробактерій). Тоді як у другому досліді (O), цей індекс коливався від 2,18-2,39 і був досить низьким.

6. Фітодобавку “Aditívum do kŕmnych zmesí na báze pamajoránu” в склад якої входять бактерії Lactobacillus plantarum 3 0,05\% екстрактом ефірної олії $O$. vulgare L. (LO) можна рекомендувати як пробіотик для згодовування поросятам-сисунам і відлученому молодняку для профілактики інфекційних захворювань. 


\section{References}

Darmohray, L.M. (2012). Biotransformatsiya pozhyvnykh rechovyn netradytsiynykh kormiv v orhanizmi tvaryn. Monohrafiya, L'viv (in Ukrainian).

Darmohray, L.M., \& Gonchar, M.V. (2015). Bioactivity of Pure Cultures of Bacteria and Yeast in the Background Action of the Water Extract of a Plant Galega orientalis (Lam). Research \& Reviews: Journal of Veterinary Sciences, 1(1), 82-85. http://www.rroij.com/open-access/bioactivity-of-purecultures-of-bacteria-and-yeast-in-the-backgroundaction-of-the-water-extract-of-a-plant-galegaorientalis-lam.php?aid=59849.

Darmohray, L.M., Gutyj, B.V., \& Darmohray, O.O. (2018). Antimicrobic activity concept of water extract of plants Galega orientalis (Lam.). Scientific Messenger of Lviv National University of Veterinary Medicine and Biotechnologies. 20(87), 122-125. doi: $10.15421 /$ nvlvet 8724 .

Darmohray, L.M., Orishchuk, O.S., Tsap, S.V., \& Chernenko, O.M. (2019). Environmental justification for using of active yeast in laying hens diet. Ukrainian Journal of Ecology, 9(2), 189-194. https:/www.ujecology.com/abstract/environmentaljustification-for-using-of-active-yeast-in-laying-hensdiet-43898.html.

De Martino, L., De Feo, V., Formisano, C., Mignola, E., \& Senatore, F. (2009). Chemical Composition and Antimicrobial Activity of the Essential Oils from Three Chemotypes of Origanum vulgare L. ssp. hirtum (Link) Ietswaart Growing Wild in Campania (Southern Italy). Molecules, 14, 27352746. doi: 10.3390/molecules 14082735 .

Gutiérrez-Grijalva, E.P., Picos-Salas, M.A., Leyva-López, N., Criollo-Mendoza, M.S., Vazquez-Olivo, G., \& Heredia, J.B. (2018). Flavonoids and Phenolic Acids from Oregano: Occurrence, Biological Activity and Health Benefits. Plants, 7(1), 2-23. doi: 10.3390/plants7010002.

Iskra, R.Ia. (2012). Aktyvnist enzymiv vuhlevodnoho obminu ta vmist hliukozy v krovi svynomatok i porosiat za dodavannia do ratsionu nanotsytratu khromu. Naukovi dopovidi NUBiP, 8(30), 2-8 (in Ukrainian).

Lukas, B., Schmiderer, C., \& Novak, J. (2015). Essential oil diversity of European Origanum vulgare L. (Lamiaceae). Phytochemistry, 119, 32-40. doi: 10.1016/j.phytochem.2015.09.008.

Marcin, A., Lauková, A., Molnárová, J., \& Valiga, I. (2004). Využitie pamajoránovej a šalviovej silice pre zlepšenie produkčných a zdravotných parametrov odstavených prasiat. http://old.agroporadenstvo.sk/rv/ liecivky/vyuz_silice.htm (in Slovak).

Martyshuk, T.V., \& Gutyj, B.V. (2019). Influence of feed additive "Butaselmevit-Plus" on antioxidant status of rats in conditions of oxidative stress. Scientific Messenger of Lviv National University of Veterinary Medicine and Biotechnologies. Series: Agricultural sciences, 21(90), 76-81. doi: 10.32718/nvlvet-a9013.
Milevskaya, V.V., Temerdashev, Z.A., Butyl'skaya, T.S. et al. (2017). Determination of phenolic compounds in medicinal plants from the Lamiaceae familyJ. Anal Chem., 72, 342. doi: 10.1134/S1061934817030091.

Milos, M., Mastelic, J., \& Jerkovic, I. (2000). Chemical composition and antioxidant effect of glycosidically bound volatile compounds from oregano (Origanum vulgare L. ssp. hirtum). Food Chemistry, 71(1), 7983. doi: 10.1016/S0308-8146(00)00144-8.

Mith, H., Dure, R., Delcenserie, V., Zhiri, A., Daube, G., \& Clinquart, A. (2014). Antimicrobial Activities of Essential Oils and Their Components against FoodBorne Pathogens and Food Spoilage Bacteria. Food Science \& Nutrition, 2, 403-416. doi: 10.1002/fsn3.116.

Oravec, V., Varga, I., Repcak, M., Hulikova, A., \& Cerny, J. (1988). Patent No. 245316, Office for Patents and Discoveries, Czechoslovak Republic (in Slovak).

Peleno, R.A. (2019). Mikrobiotsenoz kyshechnyku ta imunnyi status porosiat za nematodozno-protozooznoi invazii i khimioprofilaktyky. Lvivskyi natsionalnyi universytet veterynarnoi medytsyny ta biotekhnolohii imeni S.Z. Gzhytskoho. Dr. Vet. Sci [thesis], Lviv (in Ukrainian).

Poracova, J., \& Sutiakova, I. (2003). Fytogenne krmne aditiva $\mathrm{z}$ liecivych rastin a ich vyuzitie vo zvysovani kvality produktov $\mathrm{v}$ zivocisnej vyrobe. In: Kvalitativne aspekty pestovania a spracovania liecivych, aromatickych a koreninovych rastlin: zbornik z odborneho seminara s medzinarodnou ucast'ou, Agroinstitut Nitra, 4. decembra 2003. Nitra: Agroinstitut, 4245 (in Slovak).

Salamon, I., \& Hrytsyna, M. (2019). Veterinary Medicine and the Use of Medicinal Plants. Scientific Messenger of LNU of Veterinary Medicine and Biotechnologies. Series: Veterinary Sciences, 21(94), 121-126. doi: 10.32718 /nvlvet9422.

Salamon, I., Kryvtsova, M., Bucko, D., \& Tarawneh Amer, H. (2018). Chemical characterization and antimicrobial activity of some essential oils after their industrial large-scale distillation. The Journal of Microbiology, Biotechnology and Food Sciences, 8(3), 965969. doi: 10.15414/jmbfs.2018-19.8.3.965-969.

Shesterynska, V.V., Trokoz, V.O, Karpovskyi, V.I., Maksin, V.I., \& Kryvoruchko, D.I. (2012). Dynamika vmistu hliukozy v krovi svynei riznykh typiv nervovoi systemy za umov dodavannia do ratsionu "Iodiskontsentratu". Biolohiia tvaryn, 14(1), 295-299 (in Ukrainian).

Stybel, V., Gutyj, B., Hariv, I., Slivinska, L., \& Prijma, O. (2019). Effect of "Amprolinsyl" and "Amprolium $22 \%$ " on morphological indices of blood of turkeys for eumeria invasion. Scientific Messenger of Lviv National University of Veterinary Medicine and Biotechnologies. Series: Veterinary sciences, 21(94), 157-162. doi: 10.32718/nvlvet9429. 